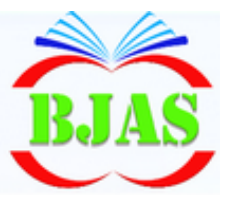

Available online at http://bajas.edu.iq https://doi.org/10.37077/25200860.2019.263 College of Agriculture, University of Basrah
Basrah Journal of Agricultural Sciences

ISSN $1814-5868$

Basrah J. Agric. Sci., 32 (Spec. Issue 2): 134-139, 2019

E-ISSN: 2520-0860

\title{
Effect of Seaweed Extract Spray on Vegetative and Flowering Growth of Two Narcissus Species
}

\author{
Ayat H.M. Al-Khuzaey* \& Fatimah A.H. Al-Asadi
}

Department of Horticulture and Landscape, College Agriculture University of Basrah, Iraq

*Corresponding author e-mail: ayattfarah@gmail.com

Received 19 September 2019; Accepted 18 November 2019; Available online 22 November 2019

\begin{abstract}
An experiment was carried out in the Cloth Canopy, Agricultural Research Station, College of Agriculture, University of Basrah, during the agricultural season 2018-2019, to study the effect of the seaweed extract spray $\left(0,2\right.$ and $\left.4 \mathrm{~m} \cdot \mathrm{L}^{-1}\right)$ on vegetative and flowering growth of two Narcissus species. Local white flowers (Narcissus tazetta) and the imported yellow flowers ( $N$. eastertide). A factorial experiment with Randomized Completely Block Design (R.C.B.D) were used, with three replicates, the averages were compared using Least Significant Difference (L.S.D). When the plants reached treated at the emergence completion, leaves were sprayed to wetness full, with three times, the process was repeated every 15 days. The results showed that the white variety was significantly higher as well as plants treated with 4 m. $\mathrm{L}^{-1}$ extract showed significant superiority in all studied traits, the interaction between the white variety and spraying with seaweed extract concentration of $4 \mathrm{~m} \cdot \mathrm{L}^{-1}$ had a significant on the number of leaves5.00 leaf plant ${ }^{-1}$, leaf area $818 \mathrm{~cm}^{2}$, fresh and dry weights (30.16 and $15.70 \mathrm{~g}$ ) of the vegetative total, flower stem length $45.55 \mathrm{~cm}$, vase life 17.29 day. while the interaction between the yellow species and spraying with seaweed extract concentration of $4 \mathrm{~m} . \mathrm{L}^{-1}$ had a significant on fresh and dry weight of the flowers (16.80 and $1.73 \mathrm{~g}$ ).

Key words: Flowering, Narcissus, Spraying, Seaweed Extract, Species, Vegetative Growth.
\end{abstract}

\section{Introduction}

Narcissus bulbs were Amaryllidaceae family plants, the most common annual winter bulbous in Iraq, cluster species Narcissus tazetta L. grow wild in the northern regions of Iraq, it spreads in Amadiyah, Shaqlawa, Sulaymaniyah and Mosul (Townsend et al., 1985). In Europe, there are large areas devoted to plant the flowers, the cultivated areas in Britain in 1990 was 3972 hectares, while in the Netherlands it was 1,639 hectares in 1992 (ADAS, 1992). The organic fertilizers and herbal extracts spray was widely the techniques, that have been used as bio stimulants for plant physiological functions. It contains stimuli and plant hormones that important for growth, leads to increased growth, as a result of nutrient uptake, as well as resistance to freezing and diseases, the output was positively reflected and its quality improved (Jassim \& Al-Dulaimi, 2014).

Organic fertilization increases plant productivity from vegetative growth and the amount of volatile oil (Said Al-Ahl et al., 2009). Recent studies have shown that the Narcissus plant varied its growth and productivity according to different species. Miller (2002) indicated that a significant differences in vegetative and floral traits when cultivating Narcissus species (Primeur, 
Excetion ice, Pink charm and Carlton). AlSaad \& Izzedine (2014) showed that the cheerfulness yellow variety of Narcissus plant significantly superior to Accent, mixed, Red Devon, while the mixed variety appeared early of the colour appearance date, the Accent c variety significantly exceeded of the flower diameter. Al-Asadi (2016) found that spraying Freesia hybrid L. with seaweed extract $\left(5 \mathrm{mg}\right.$. $\left.\mathrm{L}^{-1}\right)$ gave the best results compared to concentrations 0 and $2.5 \mathrm{mg} . \mathrm{L}^{-1}$. Al-Bayaty \& Al-Kalefa (2017) noted that there was no significant effect when adding Alga 600 fertilizer at a concentration of $(0$ and $3 \mathrm{~g} \mathrm{~L}^{-1}$ ) to tow species of Narcissus (Salome) white colour and (Tahiti) yellow colour.
The aim of this study is to investigate the effect of spraying with seaweed extract (Agazone) with three concentrations of 0,2 and $4 \mathrm{~m} . \mathrm{L}^{-1}$ on the vegetative and flowering growth of two Narcissus variety: The local white flowers ( $N$. tazetta) and the imported yellow flowers ( $N$. eastertide) .

\section{Materials \& Methods}

Bulbs were planted in $26 \mathrm{~cm}$ diameter plastic pots, filled with a medium of 2: 1 river atomic and Peatmoss, several random samples of soil were taken before planting, to determine some of the chemical and physical properties that were conducted in the Central Laboratory of the College of Agriculture, University of Basrah (Table 1.).

Table (1): Some physical and chemical properties of soil before planting.

\begin{tabular}{cc}
\hline Properties & Value \\
\hline Electrical Conductivity (E.C.) ds. ${ }^{-1}$ & 1.54 \\
\hline $\mathrm{pH}$ & 7.51 \\
\hline Available nitrogen $\left(\mathrm{mg}^{-\mathrm{kg}^{-1}}\right)$ & 171.00 \\
\hline Available phosphorus & 4.64 \\
\hline Available potassium & 57.17 \\
\hline Organic Matter \% & 1.84 \\
\hline Soil type & \\
\hline Sand (g.kg $\left.{ }^{-1}\right)$ & 861.8 \\
\hline Silt & 80.84 \\
\hline Clay & 57.36 \\
\hline Soil texture & Sandy loam \\
\hline
\end{tabular}

The solution was prepared from the extract, added the diffuser Tween 20, leaves were sprayed to wetness full, with three times, the process was repeated every 15 days. Spray fungicides and fertilizer with compound fertilizer 20: 20: 20 for all plants.

Traits at the flowering stage included vegetative growth, leaf length $(\mathrm{cm})$, leaves number (leaf plant The growth flowers stage included the flowering date (day), fresh and dry weight of the flower $(\mathrm{g})$, length of flower stem $(\mathrm{cm})$ and vase life (day).

A factorial experiment with Randomized Completely Block Design (RCBD) were used, with three replicates, Least Significant Difference (L.S.D) was used to compare the mean averages of the coefficients at the level 0.05 (Al-Rawi \& Khalaf Allah, 1980).

The sea algae extract used in the experiment as proven in the label of the 
container contains nitrogen as a free mineral and natural growth stimulants that include auxins, gibberellins, cytokinins, carbohydrates and amino acids, and minor mineral elements such as manganese, magnesium, calcium, zinc, boron and iron.

\section{Results \& Discussion}

Effect of the spraying with seaweed extract on vegetative and flowering growth of two species Narcissus

Table (2). showed the significant superiority of the white species ( $N$. tazetta) compared to the yellow $\operatorname{species}(N$. eastertide) on vegetative growth traits. Spraying with seaweed extract had significant superior at a concentration of $4 \mathrm{~m} \cdot \mathrm{L}^{-1}$ on leaves number, leaf area, soft and dry weight of the vegetative plant, which amounted to 4.944 leaf plant $^{-1}$, $646.4 \mathrm{~cm}^{2}, 28.019$ and $14.8876 \mathrm{~g}$ respectively, compared with the control treatment which was 4.333 leaf plant ${ }^{-1}, 489.3 \mathrm{~cm}^{2}, 21.500$ and $10.7712 \mathrm{~g}$ respectively.

The interaction between the species and seaweed extract had a significant effect in improving the indicators of vegetative growth, white species with seaweed extract recorded the highest concentration of $4 \mathrm{~m} . \mathrm{L}^{-1}$ in vegetative traits, reached 5,000 leaves ${ }^{-1}$, $818.8 \mathrm{~cm}^{2}, 15,7007$ and $30,168 \mathrm{~g}$ respectively, comparing with untreated yellow variety plants with seaweed extract 4.067 leaves $^{-1}$, $376.6 \mathrm{~cm}^{2}, 2.9 .8090$ and $20.41 \mathrm{~g}$ respectively

Table (2): Effect of spraying with seaweed extract on vegetative growth of two Narcissus species.

\begin{tabular}{|c|c|c|c|c|c|}
\hline Species & $\begin{array}{c}\text { Seaweed extract } \\
\left(\mathrm{m} \cdot \mathrm{L}^{-1}\right)\end{array}$ & $\begin{array}{l}\text { leaves number } \\
\text { (leaf plant }^{-1} \text { ) }\end{array}$ & $\begin{array}{c}\text { leaf area } \\
\left(\mathrm{cm}^{2}\right)\end{array}$ & $\begin{array}{c}\text { fresh weight } \\
\text { of total } \\
\text { vegetative } \\
(\mathrm{g})\end{array}$ & $\begin{array}{l}\text { dry weight of } \\
\text { vegetative growth } \\
(\mathrm{g})\end{array}$ \\
\hline $\mathrm{Y}$ & & 4.430 & 421.2 & 23.238 & 11.9241 \\
\hline $\mathrm{W}$ & & 4.852 & 714.4 & 26.513 & 13.9930 \\
\hline \multicolumn{2}{|r|}{ L.S.D 0.05} & 0.0582 & 4.82 & 0.0553 & 0.03569 \\
\hline & 0 & 4.333 & 489.3 & 21.500 & 10.7712 \\
\hline & 2 & 4.644 & 567.7 & 25.108 & 13.2169 \\
\hline & 4 & 4.944 & 646.4 & 28.019 & 14.8876 \\
\hline \multicolumn{2}{|r|}{ L.S.D 0.05} & 0.0713 & 5.90 & 0.0677 & 0.04193 \\
\hline \multirow{3}{*}{ Y } & 0 & 4.067 & 376.6 & 20.411 & 9.8000 \\
\hline & 2 & 4.333 & 412.9 & 23.433 & 11.8889 \\
\hline & 4 & 4.889 & 474.0 & 25.870 & 14.0746 \\
\hline \multirow{3}{*}{ W } & 0 & 4.600 & 601.9 & 22.589 & 11.7334 \\
\hline & 2 & 4.956 & 722.5 & 26.783 & 14.5450 \\
\hline & 4 & 5.000 & 818.8 & 30.168 & 15.7007 \\
\hline \multicolumn{2}{|c|}{ L.S.D 0.05} & 0.1008 & 8.35 & 0.0958 & 0.05734 \\
\hline
\end{tabular}

The superiority of the white variety may be due to genetic factors (Sultan et al., 1992), the superiority of plants treated with seaweed extract, due to the extract content of nutrients, growth regulators and amino acids, which improve the vegetative growth represented by increasing the number of leaves (Al-Sahaf, 1989). Increasing the leaf area with increasing concentrations of seaweed extract due to the nutrients in the extract, including potassium, increases the metabolic activities of the plant, 
formation of amino acids and protein, as well as chlorophyll formation, which important in the photosynthesis process, the carbohydrates formation, that lead to increased vegetative growth, which increases the size of the plant and leaf area, the weight gain of the vegetative growth when treated with the extract may be due to the components of seaweed extract of nutrients, which have a vital effect on plant activity, thus increasing their absorption of nutrient elements by the plant which increases the vegetative growth of the plant (Osman et al., 2010). Growth regulators, like cytokines, stimulate plant growth at lower temperatures (Dieleman et al., 1997).

\section{Effect of spraying with seaweed extract on Flowering growth of two species Narcissus:}

Table (3). Indicated that the flowering growth in white variety was significantly affected by seaweed extract, superiority in vase life, flower stem length, fresh and dry weight of flowers compared to yellow variety plants. Plant sprinkled with seaweed extract at a concentration of $4 \mathrm{~m} . \mathrm{L}^{-1}$ recorded the highest rate on fresh weight flower, dry weight and vasa life reached 8.8140 days, $37.696 \mathrm{~cm}$, 0.9096 and $17.700 \mathrm{~g}$ respectively, compared with control treatment which amounted to 6.1133 days, $34.981 \mathrm{~cm}, 12.478$ and $0.6625 \mathrm{~g}$ respectively. The effect of the interaction between the seaweed extract and species was significant in improving flowering growth, white species treated with $4 \mathrm{~m} \mathrm{~L}^{-1}$ of seaweed extract record the highest rate in vase life, flower stem length, fresh and dry weight of flowers, reached 17.293 days, $45.553 \mathrm{~cm}$ 0.0859 and $0.8183 \mathrm{~g}$ respectively, compared to the untreated yellow variety 12.182 days, $26.620 \mathrm{~cm}$ respectively, while the lowest fresh and dry weight of the flowers resulted from the white variety untreated extract 0.0652 and $0.5742 \mathrm{~g}$ respectively.

Table (3): Effect of the spraying with seaweed extract on flowering growth of two Narcissus species.

\begin{tabular}{|c|c|c|c|c|c|}
\hline Species & $\begin{array}{c}\text { Seaweed } \\
\text { extract }\left(\mathrm{m} . \mathrm{L}^{-1}\right)\end{array}$ & $\begin{array}{c}\text { Vase life } \\
\text { (day) }\end{array}$ & $\begin{array}{l}\text { length of } \\
\text { flower stem } \\
\quad(\mathrm{cm})\end{array}$ & $\begin{array}{l}\text { fresh weight of } \\
\text { the flower }(\mathrm{g})\end{array}$ & $\begin{array}{l}\text { dry weight of } \\
\text { the flower }(\mathrm{g})\end{array}$ \\
\hline $\mathrm{Y}$ & & 15.330 & 28.259 & 14.5106 & 1.4865 \\
\hline $\mathrm{W}$ & & 15.317 & 44.737 & 0.6896 & 0.0750 \\
\hline & L.S.D 0.05 & 0.1825 & 0.1454 & 0.01967 & 0.01388 \\
\hline & 0 & 12.478 & 34.981 & 6.1133 & 0.6625 \\
\hline & 2 & 15.792 & 36.816 & 7.8729 & 0.7702 \\
\hline & 4 & 17.700 & 37.696 & 8.8140 & 0.9096 \\
\hline & L.S.D 0.05 & 0.1290 & 0.1781 & 0.02409 & 0.01700 \\
\hline \multirow{3}{*}{$\mathrm{Y}$} & 0 & 12.182 & 26.620 & 11.6524 & 1.2598 \\
\hline & 2 & 15.700 & 28.317 & 15.0697 & 1.4664 \\
\hline & 4 & 18.107 & 29.839 & 16.8097 & 1.7332 \\
\hline \multirow{3}{*}{ W } & 0 & 12.773 & 43.342 & 0.5742 & 0.0652 \\
\hline & 2 & 15.883 & 45.316 & 0.6761 & 0.0739 \\
\hline & 4 & 17.293 & 45.553 & 0.8183 & 0.0859 \\
\hline \multicolumn{2}{|r|}{ L.S.D 0.05} & 0.1825 & 0.2519 & 0.03407 & 0.02404 \\
\hline
\end{tabular}


Plants treated with seaweed extract were superior in flowering properties, as a result of seaweed extract contains zinc, a catalyst for oxidative stress in plant cells, regulates the consumption of sugars, increases the energy in the plant, participates in the formation of starch, increases the carbohydrate content and thus prolongs the flowering life of the plant (Jyung et al., 1975; Al-Rayes, 1987). Seaweed extract contains an integrated composition of nutrients, increased plant readiness, transmission by vegetative parts, raising the efficiency of vital activities in vegetative total, cell division and elongation, increased length of flower stand (Al-Rayes, 1987). The reason for the increase in fresh and dry weight of flowers, important compounds of growth, increases the efficiency of photosynthesis, improved vegetative and radical growth, positively reflected in the increase in carbohydrate intake (Naseem, 2009).

\section{Conclusions}

We conclude from the study that the white variety was superior in all studied traits and spraying with seaweed extract with a concentration of $4 \mathrm{~m} . \mathrm{L}^{-1}$ the best concentrations used in the experiment.

\section{Acknowledgment}

We would like to the thank Department of Horticulture and Landscape Design, Prof. Dr. TahaY. M. Al-Edany from Department of Plant Protection for identification of the plants of this study. College of Agriculture, University of Basrah for space and resources and scientific for this research.

\section{References}

ADAS (1992). Areas and values. bulbs \& allied Crops-England \& Wales. agricultural development \& advisory service bulbs crop notes. (Cited from Hanks, G. R. 1992. Narcissus. In De Hertogh, A. \& Le Nard, M. (Eds.). The Physiology of Flower Bulbs. Elsevier, Amsterdam: 812pp.

Al-Asadi, Z.N. (2016). Responses of Freesia hybrid L. to the Spraying with Liquid Coconut and seaweed extract and effect of vegetative growth and yield. Basrah J. Agric. Sci., 29(2): 594-607.

Al-Bayaty, M.Y. \& Al-Kalefa, A.K. (2017). Effect drench alga 600 and humic acid on growth and flowering of two cultivar from Narcissus spp. Tikrit J. Agric. Sci., 17(Spec. Issue) :30-38. (in Arabic).

Al-Rawi, K. M. \& Khalaf Allah, A.M. (1980). Design and Analysis of Agricultural Experiments. Univ. Mosul Press: 488pp. (in Arabic).

Al-Rayes, A.H.J. (1987). Plant Nutrition. Part I: Aspects of Plant Nutrition. Min. High. Educ. Sci. Res., Univ. Baghdad .224 pp . (in Arabic).

Al-Sahaf, F.H. (1989). Applied Plant Nutrition. House of Wisdom, Min. High. Educ. Sci. Res., Univ. Baghdad: 258pp. (in Arabic).

Dieleman, J. A. F.; Verstappen, W. A.; Canden, B. N.; Kuiper, D. \& Tromp, J.(1997). Cytokinins in Rosa hybrida in relation in to bud break. Physiol. Plant., 99(3): 456-464.

Jassim, A.H. \& Al-Dulaimi, Q.L. (2014). Effect of adding organic fertilizers and foliar application of humic acid \& seaweed extract in growth \& green pod yield of broad bean (Vicia faba L.). Euphrates J. Agric. Sci., 6(1): 163-172. (In Arabic).

Jyung, W.H.; Ehmann, A. ; Schlender, K . K . and Scala, J . (1975). Zinc nutrition and 
starch metabolism in Phaseolus vulgaris L. Plant Physiol., 55: 414-420.

Miller, W.B. (2002). Height control and the use of plant growth regulators on spring bulbs. Flower bulb research program. Green House Product News, 12(5): 8-14.

Naseem, M.G. (2009). Protected Agriculture, Fundamentals and Management. El-Maaref Establishment for Printing and Publishing. Fac. Agric., Sayed Pasha, Univ. Alexandria: 377pp. (in Arabic).

Osman, S.M.; Khamis, M.A. \& Thorya, A.M. (2010). Effect of mineral and Bio-NPK soil application on vegetative growth, flowering, fruiting and leaf chemical composition of young olive trees. Res. J. Agric. Biol. Sci., 6(1): 54-63.
Saad, K.; Gh. I. \& Izzedine, M.Y. (2014). Response of five species of tulip plant (Tulipa gesneriana) to the treatment of soaking with gibberellic acid solution. $2^{\text {nd }}$ Int. Sci. Conf. Agric. Res. Univ. Kirkuk. Fac. Agric. 30-31/10/2013. (in Arabic).

Said Al-Ahl, H. A. H.; Hasnaa, S. A. \& Hendawy, S. F. (2009). Effect of potassium hum ate $\&$ nitrogen fertilizer on herb and essential oil of oregano under different irrigation intervals. J. Appl. Sci., 2(3): 319-323.

Sultan, S.M.; Chalabi, T.M. \& Sawaf, M. D. (1992). Decorations Plant. Dar Al Kutub Prin. Publ. Univ. Mosul: 446pp. (In Arabic).

Townsend, C.C.; Guest, E. (1985). Flora of Iraq. Min. Agric., Baghdad: Vol. 8: 440pp. 